DOI: https://doi.org/10.52362/jmijayakarta.v1i3.158

\title{
PERANCANGAN APLIKASI STUDENT GET STUDENT BERBASIS WEB MENGGUNAKAN FRAMEWORK LARA VEL PADA STIE \& STMIK JAYAKARTA
}

\author{
Raka Eka Saputra ${ }^{1}$, Zulhalim $^{2 *}$, Ibrahim ${ }^{3}$, Sugeng Waluyo ${ }^{4}$, Asih Septia Rini ${ }^{5}$ \\ Program Studi Sistem Informasi, Departemen Sistem Informasi, Departemen Sistem Informasi, \\ Departemen Manajemen Informatika, Departemen Teknik Informatika \\ Sekolah Tinggi Manajemen Informatika dan Komputer Jayakarta ${ }^{1,2,3,4,5}$ \\ AuthorEmail: Rakaekasaputra0110@gmail.com¹ ${ }^{1}$ zulhalim@gmail.com ${ }^{2}$, \\ ibrahim@stmik.jayakarta.ac.id ${ }^{3}$, sugeng_waluyo@stmik.jayakarta.ac.id ${ }^{4}$, \\ asihseptiarini@stmik.jayakarta.ac.id ${ }^{5}$ \\ *Correpondent Email: zulhalim@gmail.com
}

Received: 10-03-2021, Revised: 30-04-2021, Accepted: 15-05-2021

\begin{abstract}
ABSTRAK
Student Get Student yaitu program yang terdapat di Sekolah Tinggi Manajemen Informatika dan komputer STIE \& STMIK Jayakarta, dimana setiap mahasiswa dapat merekomendasikan teman, kolega, keluarga atau saudaranya untuk kuliah di STMIK Jayakarta dan dapatkan fee untuk setiap mahasiswa yang direkomendasikan. Penelitian ini bertujuan untuk membuat suatu sistem informasi aplikasi Student Get Student berbasis web. Dalam pelaksanaan kegiatan tugas akhir pada STMIK jayakarta belum melibatkan teknologi dalam pelaksanaanya. Pada tahapan proses pendataan mengharuskan mahasiswa dan pihak keuangan untuk bertemu secara langsung. Dalam beberapa kondisi,hal seperti ini tidak terlaksana dikarenakan pendataan student get student ini diharuskan untuk melakukan proses pendataan secara manual. Untuk memecahkan permasalahan-permasalahan tersebut maka penulis membangun sebuah sistem informasi untuk melakukan proses pendataan student get student secara online menggunakan metode yang digunakan untuk menyelesaikan masalah dengan metode SDLC (System Development Life Cycle). Perancangan aplikasi ini menggunakan Bahasa pemrograman PHP sebagai web service dengan framework Laravel serta database MySQL.
\end{abstract}

Kata kunci: SGS (Student Get Student), UML, Laravel, Framework

Abstract: Student Get Student is a program available at the College of Informatics Management and STIE \& STMIK Jayakarta computers, where every student can recommend friends, colleagues, family or relatives to study at STMIK Jayakarta and get a fee for each recommended student. This study aims to create a web-based information system for the Student Get Student application. In implementing the final project activities at STMIK jayakarta, technology has not been involved in its implementation. At this stage the data collection process requires students and financial parties to meet in person. In some conditions, things like this do not happen because student get student data collection is required to carry out the data collection process manually. To solve these problems, the authors build an information system to process student get student data online using the method used

This work is licensed under a Creative Commons Attribution 4.0 International License. http://journal.stmikjayakarta.ac.id/index.php/JMIJayakarta 
DOI: https://doi.org/10.52362/jmijayakarta.v1i3.158

to solve problems with the SDLC (System Development Life Cycle) method. The design of this application uses the PHP programming language as a web service with the Laravel framework and the MySQL database.

Keywords: SGS (Student Get Student), UML, Laravel, Framework

\section{PENDAHULUAN}

Pada era saat ini, perkembangan teknologi saat ini semakin pesat, dan hampir disemua aspek kehidupan bergantung pada kecanggihan teknologi. Hal ini dikarenakan efek dari kemajuan teknologi yang mampu mengoptimalkan setiap aktivitas manusia. Teknologi yang paling banyak dirasakan manusia adalah sistem informasi. Sistem informasi merupakan sebuah rangkaian kegiatan dari prosedur - prosedur yang diorganisasikan sehingga apabila dieksekusi akan menyediakan informasi untuk mendukung pengambilan keputusan. Setiap organisasi atau instansi membutuhkan dukungan sistem informasi, tak terkecuali Instansi yang bergerak di dunia pendidikan seperti perguruan tinggi juga membutuhkan dukungan teknologi sistem informasi demi meningkatkan mutu pelayanan terhadap setiap proses pendidikan.

STMIK Jakarta merupakan sebuah perguruan tinggi yang bergerak dibidang Pendidikan dengan 3 program studi yaitu S1 Sistem Informasi, S1 Teknik Informatika, D3 Manajemen Informasi. Namun sistem informasi perguruan tinggi STMIK Jakarta tidak sepenuhnya memberikan kemudahan pada para mahasiswa maupun staff yang bekerja. Salah satu masalah yang dihadapi saat ini adalah tidak adanya sistem yang memudahkan para staff untuk melakukan pendataan pada Student Get Student.

Kebutuhan sistem pengolahan data dengan berbagai macam metode yang dipakai. Dengan memanfaatkan teknologi komputer, didapat manfaat berupa kemudahan penyimpanan, mengorganisasi dan melakukan pengambilan terhadap berbagai data. Pengambilan data pada saat ini hanya menggunakan metode yang sifatnya fisik, data bisa mudah rusak dan pencarian data yang sudah diambil akan memakan waktu oleh karena itu perlu menyusun suatu sistem pengolahan data terkomputerisasi yang baik dan berguna.

Hal ini disebabkan karena di Stmik Jayakarta belum adanya sistem komputerisasi dan masih dilakukan secara manual menggunakan manual book atau Microsoft excel dengan menginput satu persatu data mahasiswa yang membawa mahasiswa baru pada kampus Stie \& Stmik Jayakarta. Oleh sebab itu, dianggap perlu dilakukan perubahan terhadap sistem yang masih dilakukan secara manual dengan menerapkan Perancangan Aplikasi student get student berbasis web menggunakan framework laravel pada Stmik Jayakarta.

Berdasarkan latar belakang diatas, maka penulis ingin mengangkat judul skripsi yang mana diharapkan dapat membantu untuk memecahkan masalah yang dilengkapi dengan judul "Perancangan Aplikasi Student Get Student Berbasis Web Menggunakan Framework Laravel Pada Stmik Jayakarta ".

\section{METODE DAN MATERI}

\subsection{Sistem}

Menurut Romney dan Steinbart dalam jurnal Penda Sudarto Hasugian, Dkk (2017:33) “ sistem adalah suatu rangkaian yang terdiri dari dua atau lebih komponen yang saling berhubungan dan saling berinteraksi satu sama lain untuk mencapai tujuan dimana sistem biasanya terbagi dalam sub sistem yang lebih kecil yang mendukung sistem yang lebih besar".

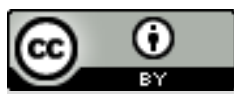




\section{DOI: https://doi.org/10.52362/jmijayakarta.v1i3.158}

Sistem terdiri dari unsur-unsur masukan (input), pengolahan (processing), serta keluaran (output) yang saling berhubungan, dan memulai satu fungsi atau tujuan utama.

\subsection{Perancangan}

Menurut Berto Nadeak, Dkk (2016:54) mendefinisikan : "Perancangan adalah langkah pertama dalam fase pengembangan rekayasa produk atau sistem. Perancangan itu adalah proses penerapan berbagai teknik dan prinsip yang bertujuan untuk mendefinisikan sebuah peralatan, satu proses atau satu sistem secara detail yang membolehkan dilakukan realisasi fisik".

Menurut Sofyan, Gustomi, \& Fitrianto (2016) Perancangan atau desain didefinikan sebagai proses aplikasi berbagai teknik dan prinsip bagi tujuan pendefinisian suatu perangkat, suatu proses atau sistem dalam detail yang memadai untuk memungkinkan realisasi fisiknya.

\subsection{Student Get Student}

Pengertian Student Get Student menurut Perguruan Tinggi Indonesia Mandiri “Suatu Program yang terdapat di Perguruan Tinggi Mandiri, dimana mahasiswa dapat merekomendasikan teman, kolega, keluarga atau saudaranya untuk kuliah di Perguruan Tinggi Indonesia Mandiri dan dapatkan imbalan yang ditentukan kampus untuk setiap mahasiswa direkomendasikan”.

\subsection{Unified Modelling Language (UML)}

Menurut Shofwan Hanief \& Dian Pramana (2018 : 166) menyatakan bahwa: "Unified Modelling Language (UML) adalah sebuah "bahasa" yang telah menjadi standar dalam industri untuk visualisas, merancang dan mendokumentasikan sistem piranti lunak".

\subsection{Boostrap}

Menurut (Nugroho \& Setiyawati, 2019), Bootstrap adalah framework css untuk membuat tampilan web. Bootstrap menyediakan class dan komponen yang sudah siap dipakai.

\subsection{Database}

Menurut Rohi Abdulloh, (2016:1) "Website adalah sekumpulan halaman yang terdiri atas beberapa laman yang berisi informasi dalam bentuk data digital, baik berupa teks, gambar, video, audio, dan animasi lainnya yang disediakan melalui jalur koneksi internet".

\subsection{Flowchart}

Dalam Lamhot Sitorus (2015:14) Untuk mengambarkan sebuah algoritma yang terstruktur dan mudah dipahami oleh orang lain (khususnya programmer yang bertugas mengimplementasikan program), maka dibutuhkan alat bantu yang berbentuk diagram alir (flowchart). Flowchart menggambarkan urutan logika dari suatu prosedur pemecahan masalah, sehinga flowchart merupakan langkah - langkah penyelesaian masalah yang dituliskan dalam simbol - simbol tertentu. Diagram alir ini akan menunjukkan alur di dalam program secara logika. Diagram alir ini selain dibutuhkan sebagai alat komunikasi, juga diperlukan sebagai dokumentasi. Berikut simbol - simbol yang digunakan dalam flowchart:

\subsection{Metode}

Metode yang dipakai untuk membangun sistem ini adalah model Waterfall. Model ini merupakan sebuah pendekatan terhadap pengembangan perangkat lunak yang sistematik, dengan beberapa tahapan yaitu :

1. Analisis dan kebutuhan

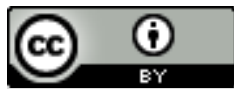

This work is licensed under a Creative Commons Attribution 4.0 International License. http://journal.stmikjayakarta.ac.id/index.php/JMIJayakarta 


\section{DOI: https://doi.org/10.52362/jmijayakarta.v1i3.158}

Prosedur pengumpulan kebutuhan dilakukan secara mendalam untuk menyampaikan keperluan perangkat lunak supaya bisa dipahami perangkat lunak sesuai apa yang dibutuhkan dengan user. Spesifikasikan kebutuhan perangkat lunak dengan tahapan ini perlu untuk di dokumentasikan.

2. Desain

Desain perangkat lunak merupakan metode langkah dalam pembuatan desain dari sebuah program perangkat lunak yang tertera dari struktur data, arsitektur perangkat lunak, gambaran antarmuka dan proses pengkodean. Bagian ini mentranslasi keperluan perangkat lunak dari tahapan analisis kebutuhan desain supaya bisa diaplikasikan menjadi sebuah program dalam tahapan selanjutnya.

3. Pembuatan Kode Program

Desain harus ditranslasikan kedalam program perangkat lunak. Proses pada tehnik ini yaitu penyusunan suatu program pada komputer sesuai dengan menggunkan desain yang sudah dibuat dalam tahapan desain.

4. Pengujian

Pengujian program dalam perangkat lunak secara mengenai sudut logika dan fungsional dengan menegaskan maka seluruh bagian dari program tersebut sudah diuji. Prihal ini dilakukan guna meminimalisir dari kelalaian (error) lalu memastikan output dari program yang dihasilkan sesuai dengan diharapkan.

5. Pemeliharaan

Pemeliharaan akan dilakukan apabila ada update fitur atau memperbaiki kesalahan yang ditemukan pada saat sistem digunakan langsung oleh user.

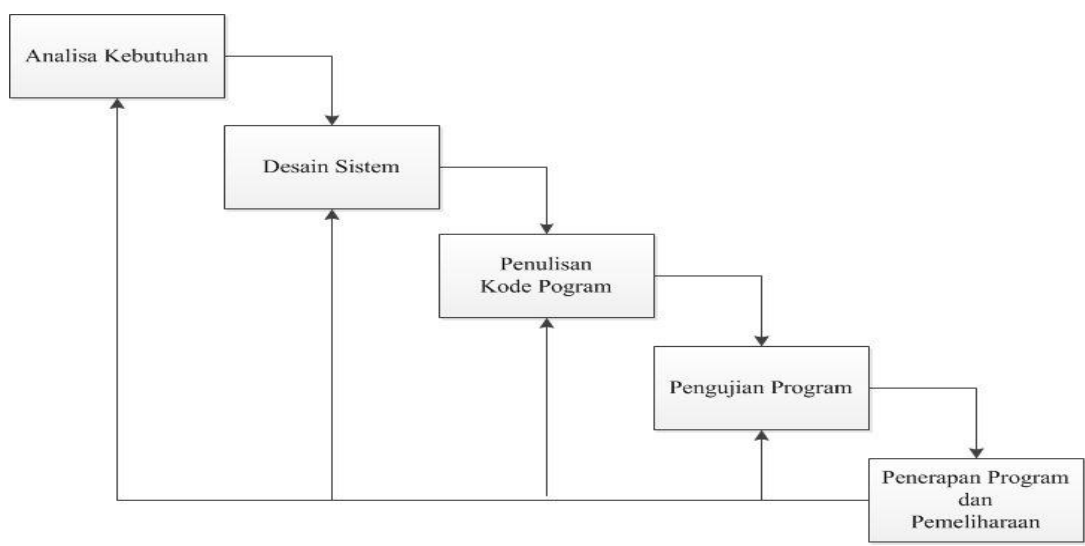

Gambar 1. Metode Waterfall

\section{PEMBAHASAN DAN HASIL}

\subsection{Rancangan Sistem}

Rancangan sistem adalah suatu sistem untuk mendeskripsikan suatu bentuk atau perancangan perangkat lunak dengan memakai teknik dan peraturan khusus sedemikian rupa sehingga bentuk atau perancangan tersebut bisa diwujudkan sebagai perangkat lunak. Pada tahap ini, penulis ini melakukan pemodelan dengan mengunakan visio. Merancang database yang akan digunakan sebagai media penyimpanan data untuk sistem Student Get Student (SGS) berbasis web dan merancang interface sebagai sarana interaksi antara sistem dengan penguna sistem.

\subsection{Use Case Diagram}

Pada Use Case diagram sistem yang sedang berjalan menjalankan fungsi - fungsi dari 2 aktor yaitu mahasiswa dan administrasi. 
DOI: https://doi.org/10.52362/jmijayakarta.v1i3.158

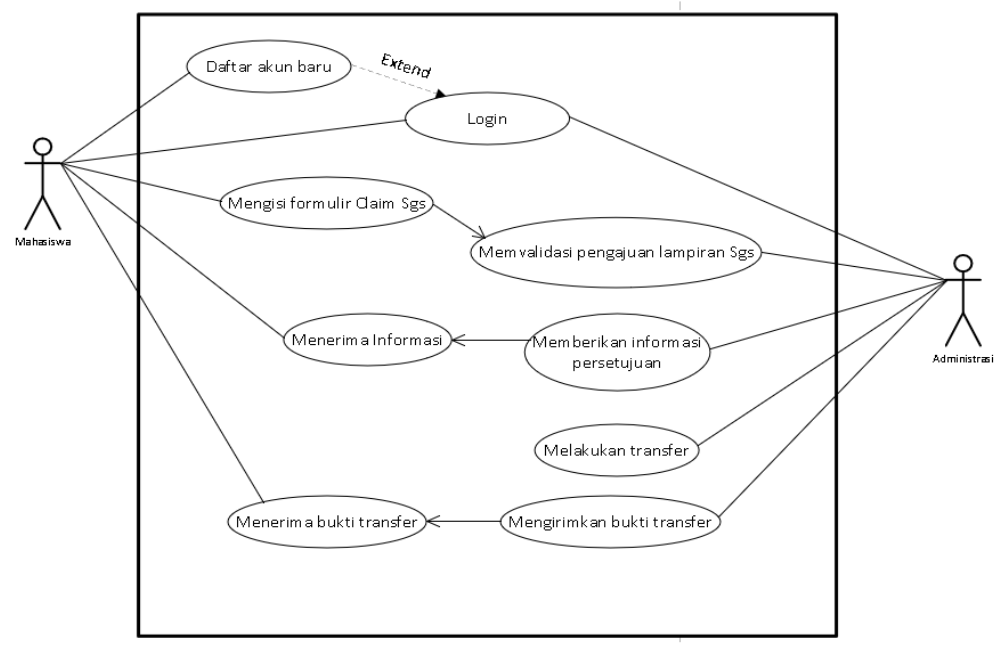

Gambar 2. Use Case Diagram yang diusul

Berdasarkan gambar 1. Use Case Diagram yang diusulkan terdapat sebagai berikut :

1. Satu sistem yang mencakup seluruh kegiatan Student Get Student (SGS)

2. Dua aktor yang melakukan kegiatan diantaranya, Mahasiswa dan Administrasi

3. Use Case yang dilakukan actor yaitu :

a. Login pada Web

b. Pengajuan Student Get Student dan mengisi formular

c. Administrasi menerima Form data mahasiswa baru

d. Administrasi memvalidasi Formulir tersebut

e. Hasil validasi diterima dan transaksi dilakukan

\subsection{Activity Diagram}

Pada gambar 4.3, menjelaskan bagaimana awal proses mahasiswa melakukan sebuah sistem Student Get Student (SGS) kepada administrasi, keputusan yang mungkin terjadi, dan bagaimana Student Get Student (SGS) tersebut berakhir. 
DOI: https://doi.org/10.52362/jmijayakarta.v1i3.158

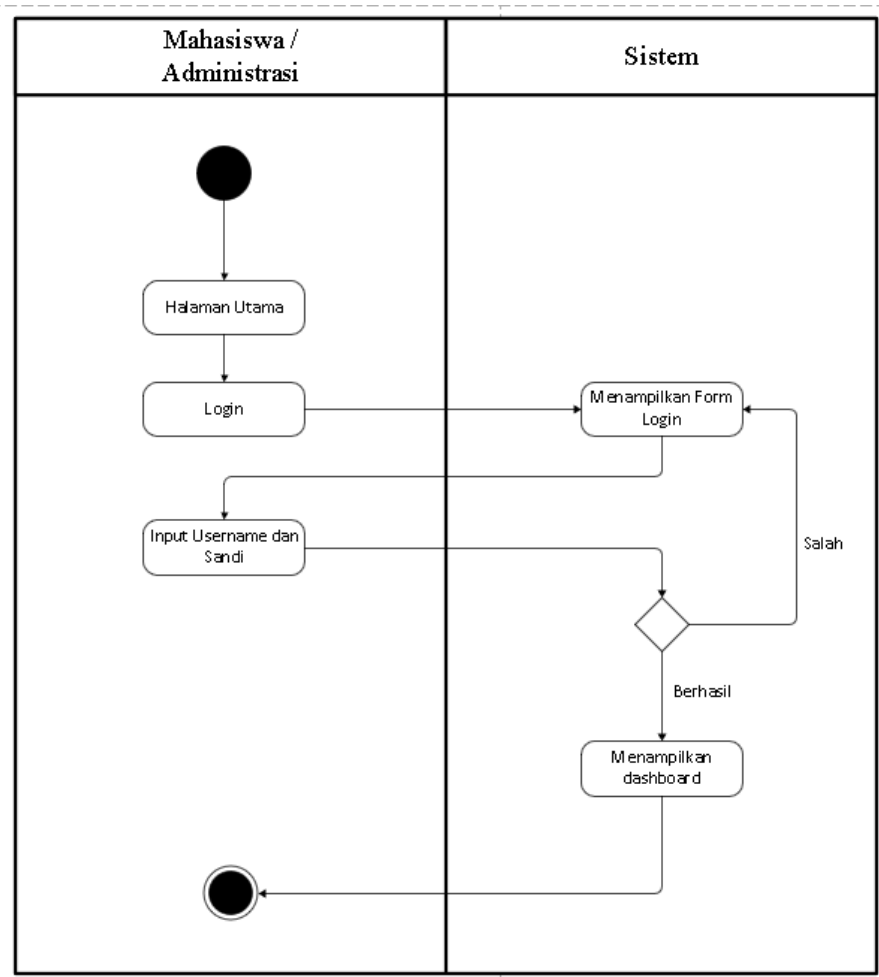

Gambar 3. Activity diagram Login

Keterangan :

a. 1 initial node, sebagai objek yang diawali

b. 5 action, sistem yang mencerminkan eksekusi dari suatu aksi yaitu:

1. Halaman Utama

2. Login

3. Menampilkan Form Login

4. Input username dan sandi

5. Menampilkan dashboard

c. 1 final state, sebagai objek diakhiri

d. Penjelasan mengenai gambar : Mahasiswa atau Administrasi melakukan login kemudian mengisi username dan sandi setelah berhasil akan memasuki halaman dashboard. 
DOI: https://doi.org/10.52362/jmijayakarta.v1i3.158

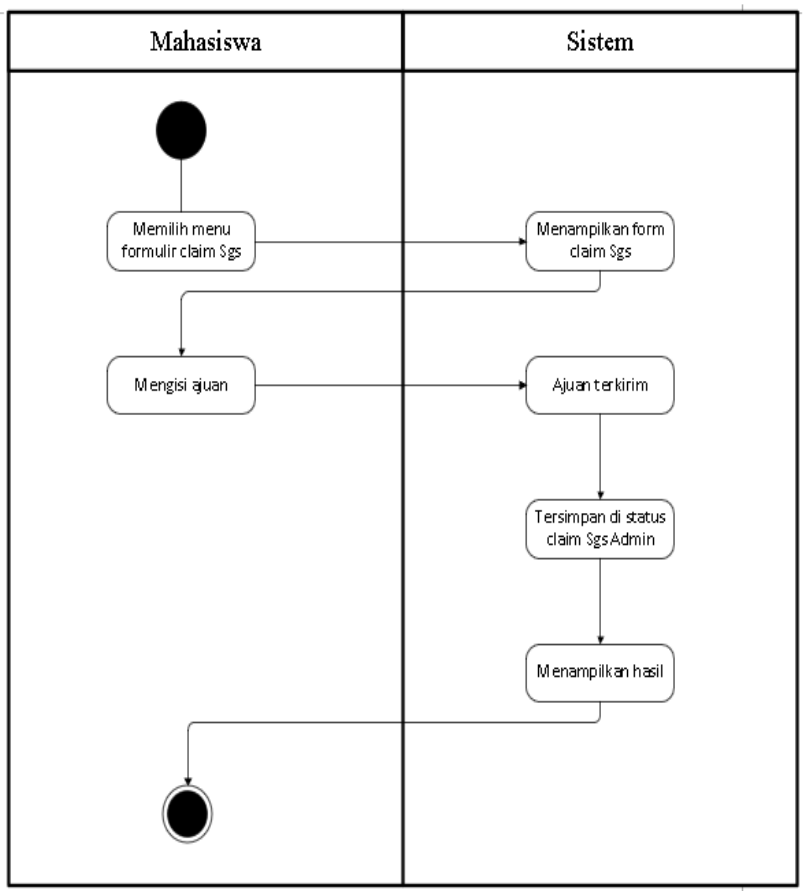

Gambar 4. Activity Diagram pengajuan Sgs

Keterangan :

a. 1 initial node, sebagai objek yang diawali

b. 6 action, sistem yang mencerminkan eksekusi dari suatu aksi yaitu :

1. Menu formulir claim $\mathrm{Sgs}$

2. Menampilkan form claim $\mathrm{Sgs}$

3. Mengisi ajuan

4. Ajuan terkirim

5. Tersimpan di dashboard admin

6. Menampilkan hasil

c. 1 final state, sebagai objek yang diakhiri

d. Penjelasan mengenai gambar : Mahasiswa mengajukan formulir claim Sgs, kemudian mengisi formulir Sgs, setelah itu ajuan surat akan dikirim. Ajuan yang terkirim akan sampai pada halaman status claim admin untuk di verifikasi 
DOI: https://doi.org/10.52362/jmijayakarta.v1i3.158

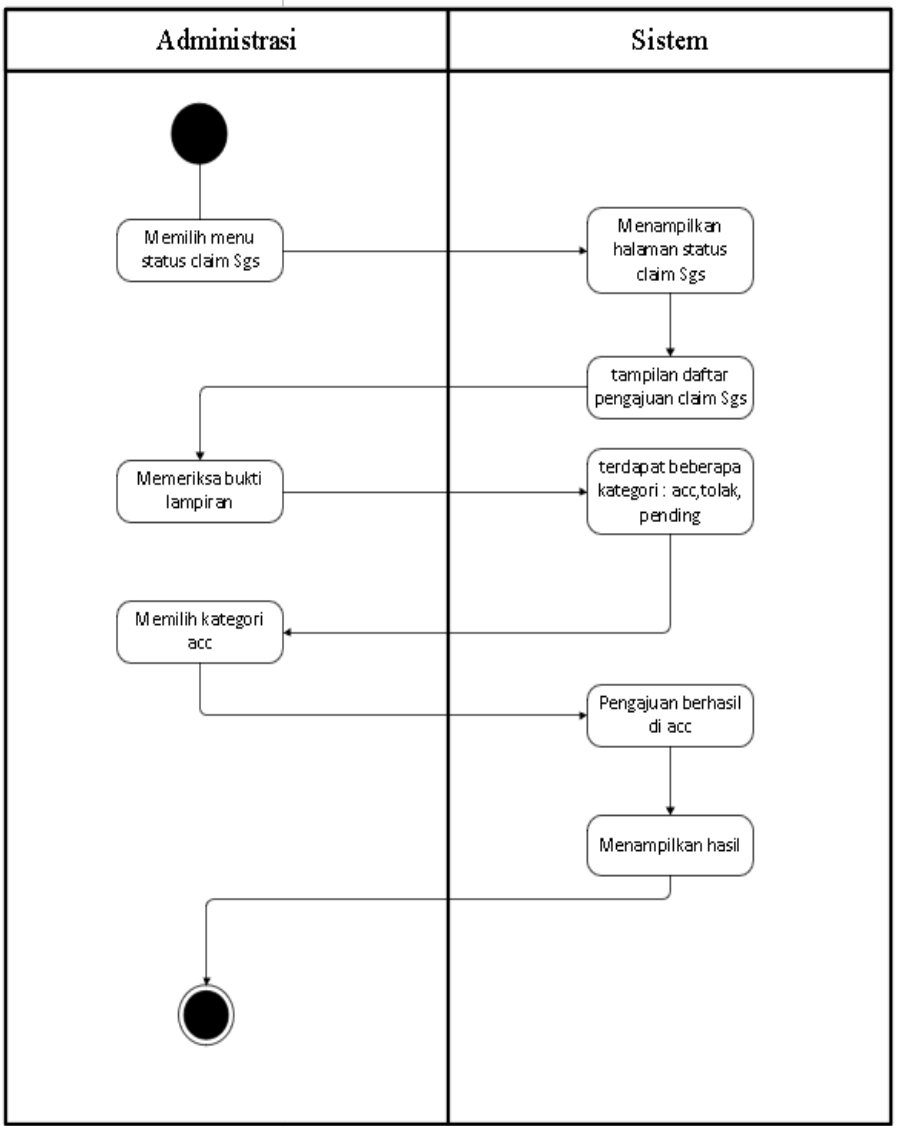

Gambar 4.5 Memeriksa dan acc pengajuan Sgs

Keterangan :

a. 1 initial node, sebagai objek yang diawali

b. 7 action, sistem yang mencerminkan eksekusi dari suatu aksi yaitu :

1. Menu status claim Sgs

2. Menampilkan halaman status claim Sgs

3. Tampilan daftar pengajuan $\mathrm{Sgs}$

4. Memeriksa bukti lampiran

5. Terdapat berbagai kategori

6. Memilih kategori acc

7. Pengajuan berhasil di acc

8. Menampilkan hasil

c. 1 final state, sebagai objek yang diakhiri

d. Penjelasan mengenai gambar, yaitu administrasi memilih status claim Sgs untuk menampilkan daftar pengajuan claim Sgs, kemudian melakukan verifikasi atau acc atas surat tersebut, surat yang telah di acc akan tersedia nantinya pada halaman status claim mahasiswa. 
DOI: https://doi.org/10.52362/jmijayakarta.v1i3.158

\subsection{Class Diagram}

Class diagram menggambarkan sebuah sistem dari pendefinisian kelas - kelas yang akan dibuat untuk membangun sistem. Berikut ini adalah class diagram dari Perancangan Aplikasi Student Get Student Berbasis Web Menggunakan Framework Laravel Pada STMIK Jayakarta.

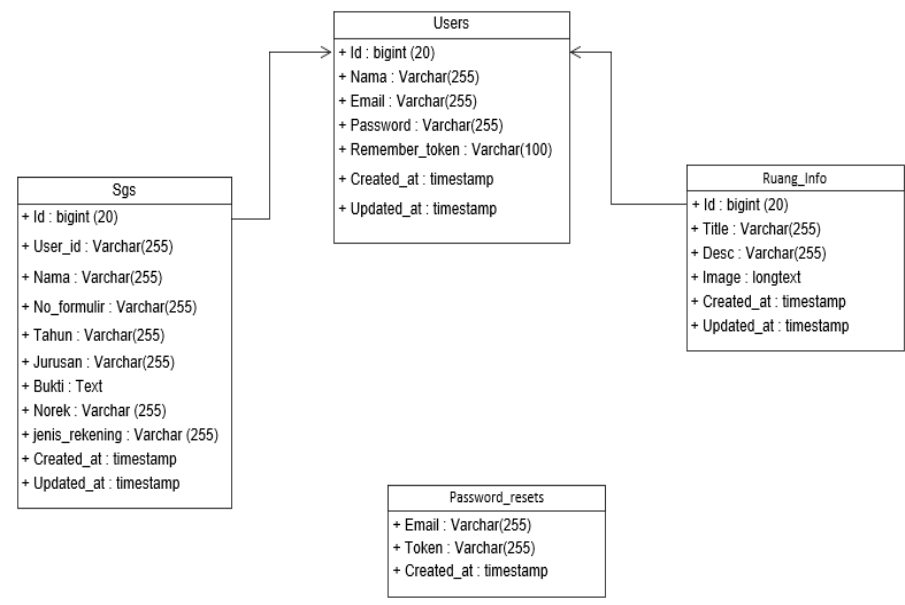

Gambar 4.6 Class Diagram pada Sistem

\subsection{Implementasi}

Berikut adalah hasil implementasi dari perancangan yang telah dibuat :

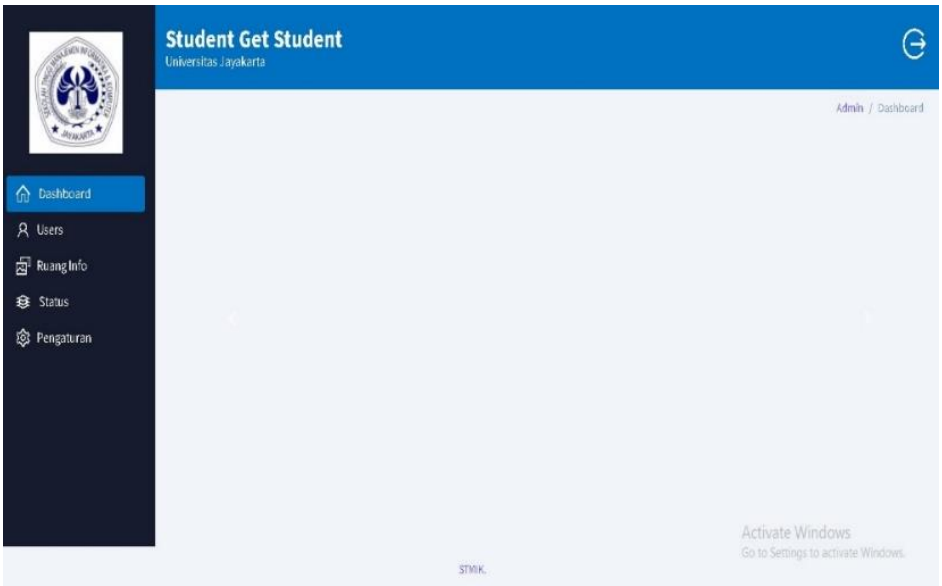

Gambar 4.13 Halaman Utama 
DOI: https://doi.org/10.52362/jmijayakarta.v1i3.158

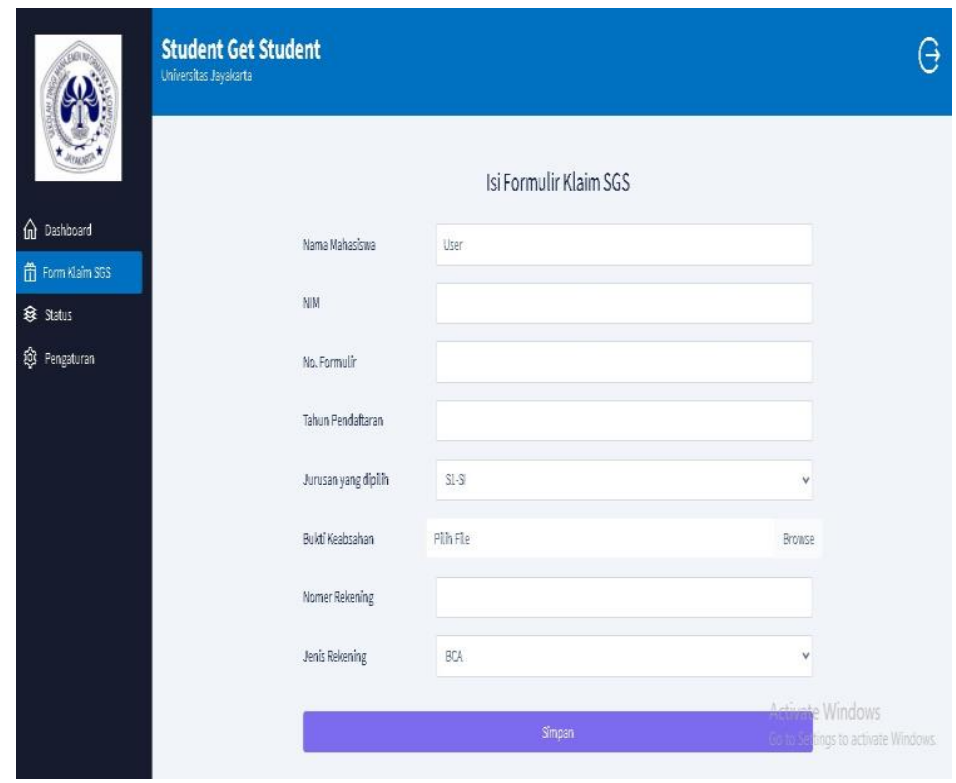

Gambar 4.16 Formulir Claim SGS

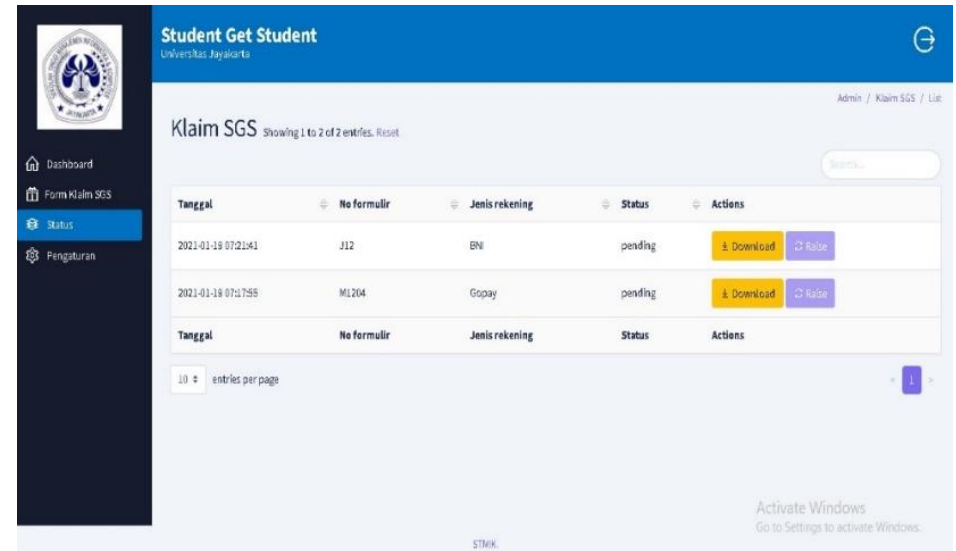

Gambar 4.17 Halaman Status Claim (User)
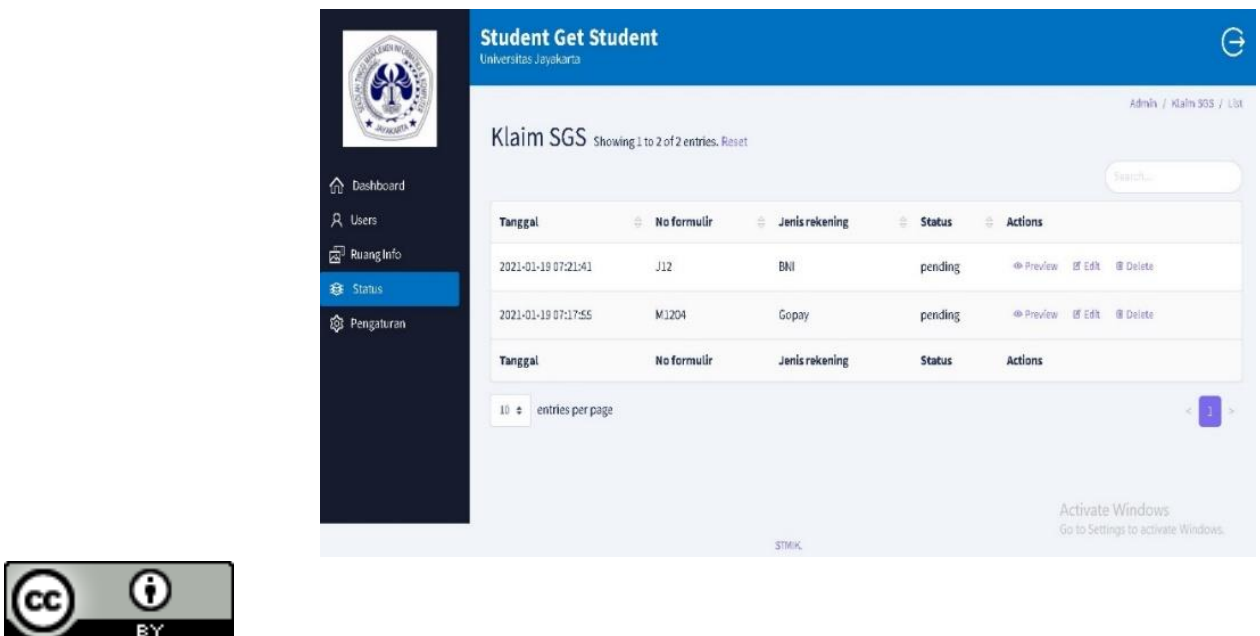

This work is licensed under a Creative Commons Attribution 4.0 International License. http://journal.stmikjayakarta.ac.id/index.php/JMIJayakarta 
DOI: https://doi.org/10.52362/jmijayakarta.v1i3.158

Gambar 4.18 Halaman Status Claim (Admin)

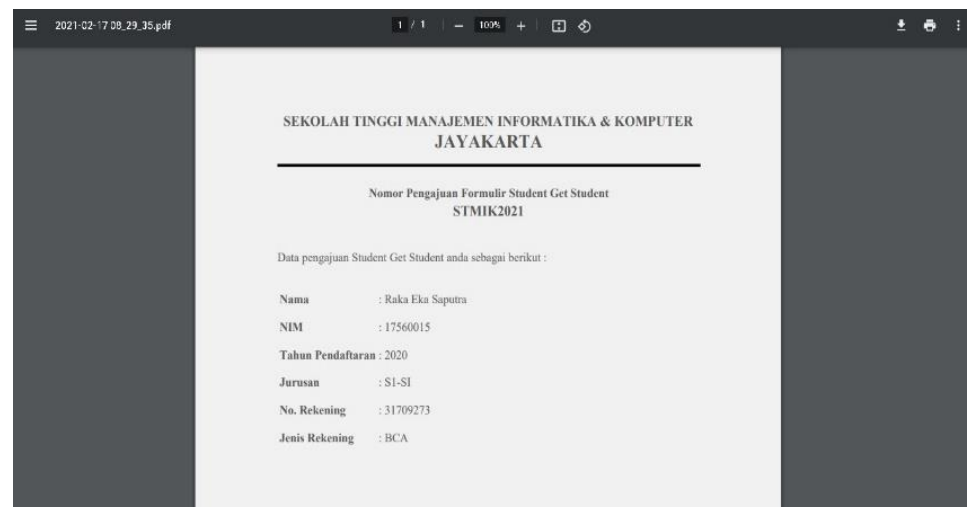

Gambar 4.19 Hasil Program

\section{KESIMPULAN}

Dari hasil penelitian yang didapat, maka penulis menarik kesimpulan bahwa:

1. Telah dihasilkan sebuah sistem aplikasi yang dapat melakukan pengajuan Sgs tanpa perlu pengajuan secara manual.

2. Telah dihasilkan sebuah sistem aplikasi berbasis web untuk pengajuan Sgs.

3. Telah dihasilkan sebuah sistem yang mampu memudahkan kepada pihak kampus dalam mencari dokumen Sgs.

\section{REFERENASI}

[1] Sunarya Triandi. (2016). Analisi dan Perancangan Sistem Informasi Administrasi Pendidikan Anak Usia Dini Berbasis Web dengan Metode Web Informasi System Development Methodology.

[2] Solihin, H. H., \& Witanto, R. (2016). Perancangan Sistem Informasi Penerimaan Siswa Baru Berbasis Web (Studi Kasus : SMP Plus Babussalam Bandung). Jurnal Infotronik.

[3] Ridha Nikmatur. (2017). Proses Penelitian, Masalah, Variabel dan Paradigma Penelitian. Jurnal Hikmah.

[4] Alpiandi, M.R. (2016). Sistem Informasi Akademik Berbasis Web di SMP Negeri 2 Kecamatan Gaung Anak Serka. Jurnal SISTEMASI.

[5] Sebayang, R. \& Hutapea, M.I. \& Simamora, R.J. (2018). Perancangan Sistem Informasi Pendataan Alumni Fakultas Ekonomi Universitas Methodist Indonesia Berbasis Web. Jurnal Manajemen Informatika \& Komputerisasi Akuntansi (METHOMIKA).

[6] Kusuma, A.P \& Widodo, T. (2016). Rancang Bangun Sistem Pendataan Nilai Akademik Siswa Berbasis Web Menggunakan PHP dan MYSQL di SMA Islam Hasanudin Kesamben. Jurnal Antivirus.

[7] Eviani, S. \& Rizki, S.D. \& Pratiwi, M. (2016). Sistem Informasi Penerimaan Siswa Baru Berbasis Web Pada SMPN 34 Kabupaten Tebo. Jurnal Teknologi.

[8] Fauzan, R. \& Indrasary, Y. \& Muthia, N. (2017). Sistem Pendukung Keputusan Penerimaan Beasiswa Bidik Misi di POLIBAN Dengan Metode SAW Berbasis Web. JOIN (Jurnal Online Informatika).

[9] Ariansyah \& Fajriyah \& Prasetyo, F.S. (2017). Rancang Bangun Sistem Informasi Pendataan Alumni Pada STIE Prabumulih Berbasis Website Dengan Menggunakan Bootstrap. Jurnal Mantik Penusa. 
DOI: https://doi.org/10.52362/jmijayakarta.v1i3.158

[10] Mumpuni, R. \& Anggraeny, F.T. \& Fadillah, M.N. (2019). Perancangan Sistem Informasi Pendataan Anggota Poliklinik UPN "Veteran" Jawa Timur. Jurnal Teknik Elektro Dan Komputasi (ELKOM).

[11] Julianti, M.R. \& Dzulhaq, M.I. \& Subroto, A. (2019). Sistem Informasi Pendataan Alat Tulis Kantor Berbasis Web pada PT Astari Niagara Internasional. JURNAL SISFOTEK GLOBAL.

[12] Siregar, V.M.M (2018). Sistem Informasi Pendataan Logistik Aktiva Tetap PT. BANK CENTRAL ASIA, Tbk Kantor Cabang Pematangsiantar. Jurnal SISTEMASI.

[13] Yasin, V. (2012). Rekayasa Perangkat Lunak Berorientasi Objek. Jakarta : Mitra Wacana Media

[14] Susilo, M. \& Kurniati, R. \& Kasmawi. (2018) Rancang Bangun Website Toko Online Menggunakan Metode Waterfall. InfoTekJar (Jurnal Nasional Informatika dan Teknologi Jaringan). 